\title{
Pola Komunikasi Kyai dengan Santri Alumni Pondok Pesantren Miftahul Huda Manonjaya
}

\author{
Yogi Anwar Sanusi ${ }^{1 *}$, Darajat Wibawa ${ }^{2}$ \\ ${ }^{1}$ Prodi Komunikasi dan Penyiaran Islam, Program Pascasarjana, \\ UIN Sunan Gunung Djati, Bandung \\ 2Jurusan Ilmu Komunikasi, Fakultas Dakwah dan Komunikasi, \\ UIN Sunan Gunung Djati, Bandung \\ *Email:yogianwarsanusi@gmail.com
}

\begin{abstract}
Every Islamic Boarding School (pondok pesantren) has different characteristics depending on leadership type and communication patterns of kyai that applied in its learning process. The theory used in this research is the communication pattern that produces a communication model referring to two communication models, linear and circular communication models in Islamic Boardingschool of Miftabul Huda Tasikmalaya. The research method is phenomenology, with the type of research data is qualitative. The results showed that the culture of communication systems in the Miftabul Huda Manonjaya boarding school embraced communication with linear and circular systems, with the forms of kyai and santri communication using instructional communication patterns through organizations, parent and child communication patterns (exemplary). The forms of kyai communication with alumni are instructional communication patterns and parent and child communication patterns (empowerment). Thus, the purpose of the pattern of kyai communication to alumni is to form and increase alumni solidarity with the same vision and mission to develop the propaganda propaganda message of the Miftabul Huda Manonjaya Islamic boarding school.
\end{abstract}

Keywords: Islamic boarding, communication, kyai, santri

\begin{abstract}
ABSTRAK
Setiap pondok pesantren memiliki ciri khas yang berbeda tergantung dari tipe leadership dan pola komunikasi kyai yang diterapkan dalam pembelajarannya. Penelitian ini bertujuan untuk mengkaji sistem budaya komunikasi, bentuk komunikasi kyai dan santri dan bentuk komunikasi kyai dengan alumni di pesantren Miftahul Huda Tasikmalaya. Teori yang digunakan dalam penelitian ini adalah pola komunikasi yang menghasilkan model komunikasi yang merujuk pada dua model komunikasi yakni model komunikasi linear dan sirkular. Metode penelitian yang digunakan dalam penelitian ini adalah fenomenologi dengan jenis penelitian kualitatif. Hasil penelitian menunjukkan bahwa budaya sistem komunikasi di Pondok Pesantren Miftahul Huda Manonjaya mengembangkan sistem komunikasi linear dan circular, dengan bentuk komunikasi kyai dan santri
\end{abstract}


menggunakan pola komunikasi melalui pola komunikasi organisasi, orang tua dan anak-anak (teladan). Bentuk komunikasi kyai dengan alumni, adalah pola komunikasi instruksional orang tua dan anak (pemberdayaan). Dengan demikian, tujuan dari pola komunikasi kyai dengan alumni adalah membentuk dan meningkatkan solidaritas alumni dengan visi dan misi yang sama untuk mengembangkan pesan dakwah di Pondok Pesantren Miftahul Huda Manonjaya.

Kata Kunci : pondok pesantren, komunikasi, kyai, santri

\section{PENDAHULUAN}

Pondok pesantren merupakan salah satu lembaga pendidikan non formal yang tersebar di Indonesia. Dimana pondok pesantren lahir ditengah-tengah masyarakat. Setiap pondok pesantren memiliki ciri khas yang berbeda-beda tergantung dari bagaimana tipe leadership-nya dan metode seperti apa yang diterapkan dalam pembelajarannya.

Pesantren adalah lembaga pendidikan Islam yang sekurang-kurangnya mempunyai tiga ciri umum yaitu kyai sebagai figur sentral, asrama sebagai tempat tinggi para santri, masjid sebagai pusat kegiatan. adanya pendidikan dan pengajaran agama Islam melalui sistem pengajian kitab dengan metode wetonan, sorogan, dan musyawarah. yang sebagian sekarang telah berkembang dengan sistem klasikal atau madrasah.

Seiring dengan perkembangan zaman, tidak sedikit pesantren yang mencoba menyesuaikan dan bersedia menerima akan suatu perubahan. namun tidak sedikit pula pesantren yang memiliki sikap penutup diri dari segala perubahan-perubahan dan pengaruh perkembangan zaman dan cenderung mempertahankan apa yang menjadi keyakinan. Untuk itu disini akan mencoba menelaah seperti apa ciri-ciri pesantren yang bersikap dinamis dan dilihat dari segi apa saja pesantren tersebut dikatakan sebagai pesantren yang bersikap dinamis. agar kita dapat melihat dan menyimpulkan sendiri apakah pesantren yang dimaksud bersikap dinamis ataukah statis.

Beberapa penelitian sebelumnya dilakukan oleh Arif Nurjaman (2015) tentang pola komunikasi kyai dalam meningkatkan solidaritas jama'ah, studi kasus tentang komunikasi kyai di Majelis Ta'lim Asy-Syifaa Wal Mahmuudiyyah Simpang Kecamatan Pamulihan Kabupaten Sumedang dengan metode kualitatif studi kasus. Hasilnya Nurjaman menyebutkan Pertama, keberadaan majelis talim sebagai wadah pengajian model salafiyyah modern. Kedua, munculnya beberapa motivasi jama'ah dalam mengikuti kegiatan yang diselenggarakan oleh majelis ta'lim, ketiga, adanya beberapa factor yang menjadi kekuatan-kekuatan yang mengikat jama'ah sehingga terbangun sebuah solidaritas yang erat seperti kesepahaman faham yang dianut yakni ablussunnah wal jama'ah dan lain-lain dan terdapatnya beberapa implikasi yang dirasakan positif oleh jama'ah setelah mengikuti pengajian yang di selenggarakan di majelis ta'lim Asy-Syifaa seperti kesederhanaan dan keberkahan dalam menjalani kehidupan. Penelitian ini 
memiliki kesamaan metode namun objek dan ruang lingkup komunikasi yang berbeda dengan peneliti. Penelitian ini Sama-sama menggunakan metode kualitatif, namun perbedaannya berada pada focus penelitian dan subjek penelitian.

Adzananda Siregar (2008) Pola komunikasi Kyai dan Santri di Pondok Pesantren Al-Asmaniyah Kampung Dukuhpinang, Tanggerang Banten dengan metode penelitian Deskriptif analis, dengan pendekatan kualitatif. Hasilnya diketahui Pola komunikasi antar pribadi, komunikasi kelompok dan komunikasi instruksional dengan menggunakan metode belajar mengajar seperti ceramah, hafalan dan lain-lain. Penelitian ini sama-sama menggunakan pendekatan kualitatif, namun perbedaannya berada pada focus penelitian dan subjek penelitian.

Melihat beberapa penelitian di atas, dapat diketahui bahwa penelitian tentang pola komunikasi kyai untuk meningkatkan solidaritas alumni di Pesantren Miftahul Huda Manonjaya Tasik belum pernah dilakukan oleh peneliti lain namun memiliki kesamaan pada jenis penelitian yaitu kualitatif. Perbedaan yang mendasar terletak pada objek dan fukos penelitian. Penelitian sebelumnya belum ada yang secara khusus meneliti tentang sistem budaya komunikasi, bentuk komunikasi kyai dengan santri dan bentuk komunikasi kyai dengan alumni.

Berdasarkan dari beberapa penelitian terdahulu dari berbagai penelitian tentang proses komunikasi, maka posisi penelitian yang akan dilakukan adalah fokus meneliti pola komunikasi yang dilakukan oleh Kyai dan Alumni Pesantren dengan merumuskan beberapa fokus penelitian yaitu sistem budaya komunikasi, bentuk komunikasi, dan sistem komunikasi yang di bangun oleh kyai, maka penelitian yang akan dilakukan menggunakan metode kualitatif.

Pesantren adalah lembaga pendidikan Islam yang sekurang-kurangnya mempunyai tiga ciri umum yaitu kyai sebagai figur sentral, asrama sebagai tempat tinggi para santri, masjid sebagai pusat kegiatan. adanya pendidikan dan pengajaran agama Islam melalui sistem pengajian kitab dengan metode wetonan, sorogan, dan musyawarah. yang sebagian sekarang telah berkembang dengan sistem klasikal atau madrasah.

Pondok Pesantren Miftahul Huda adalah salah satu lembaga pendidikan non formal. yang sampai saat ini bertahan dengan metode salafiyahnya. Pondok Pesantren Miftahul Huda didirikan oleh almarhum KH. Choer Affandi (dikenal dengan julukan Uwa Ajengan) beserta istri ( $\mathrm{Hj}$. Siti Shofiyyah) pada tanggal 7 Agustus 1967.

Di pesantren Miftahul Huda santri yang telah siap mukim atau mengamalkan ilmu di masyarakat dengan cara membuat lembaga pendidikan atau mengajar di lembaga pendidikan yang telah ada. Proses dakwah di masyarakat baik itu melalui lembaga pendidikan maupun terjun langsung dakwah dengan berbagai metode. Metode dakwah meunurut Moh. Ali Aziz terbagi atas tiga bentuk, secara khusus diklasifikasikan. Bentuk dakwah yang dapat diterapkan sesuai dengan kondisi objek mad'u. Adapun bentuk metode dakwah tersebut diklasifikasikan sebagai berikut: metode ceramah, metode diskusi, metode konseling, metode 
karya tulis, metode pemberdayaan masyarakat, metode kelembagaan (Arifin).

Karena salah satu tujuan pesantren miftahul huda yaitu menyiarkan kalimah toyyibah sesuai amanat sang pendiri maka santri yang siap mukim dan akan menjadi alumni tentu harus sudah memahami dan menguasai metode dakwah di masyarakat. Sebagaiamana di jelaskan oleh Arifudin, Metode dakwah merupakan suatu hal yang sangat penting diperhatikan dalam aktivitas dakwah. Seorang da'i ketika berdakwah diharapkan mempunyai metode yang efektif sehingga mampu menyampaikan pesan dakwahnya secara bijak dan arif (Muliadi, Dakwah Efektif: Prinsip, Metode, dan Aplikasinya).

Sedangkan menurut Muliadi, Bekal yang dibutuhkan seorang da’i seperti yang dijelaskan terkait dengan kredibilitasnya dalam aktivitas dakwah. Disamping itu, seorang da'i harus mampu untuk menjadi teladan diri pribadi maupun bagi masyarakat umum. Beberapa penelitian secara psikologi sosial menghasilkan kesimpulan bahwa manusia sebenarnya memiliki kecenderungan untuk mencontoh (Amin, 2011:63).

\section{LANDASAN TEORITIS}

Dakwah sebagai salah satu bentuk komunikasi yakni komunikasi Islam (Muis, 2001:66), memiliki berbagai tujuan seperti layaknya komunikasi. Dimana tujuan komunikasi menurut AW. Wijaya seperti dikutip Arifuddin Tike, yaitu: (1) untuk memberikan pengetian kepada penerima pesan tentang apa yang dimaksudkan oleh pemberi pesan. (2) Untuk memahami orang lain. Seseorang berkomunikasi harus mampu memahami kebutuhan orang lain sehingga apa yang disampaikannya sesuai dengan apa yang dikehendaki oleh penerima pesan maupu oleh pemberi pesan.

Pola komunikasi merupakan suatu sistem penyampaian pesan melalui lambang (symbol) tertentu, yang mengandung arti, serta sistem penciptaan makna untuk mengubah tingkah laku individu yang lain dan penggunaan pola komunikasi mempengaruhi efektifitas proses komunikasi (Onong, 2003: 10). Sedangkan menurut alex sobur, Pola adalah Bentuk atau model (atau, lebih abstrak, suatu set peraturan) yang bisa dipakai untuk membuat atau menghasilkan suatu atau bagian dari sesuatu, khususnya jika sesuatu yang ditimbulkan cukup mempunyai suatu yang sejenis untuk pola dasar yang dapat ditunjukkan atau terlihat, yang mana sesuatu itu dikatakan memamerkan pola (Alex, 2006: 376). Pola juga dapat dikatakan dengan model, yaitu cara untuk menunjukkan sebuah objek yang mengandung kompleksitas proses didalamnya dan hubungan antara unsur-unsur pendukungnya (Wiryanto, 2004: 9). Sedangkan istilah komunikasi atau communication berasal dari bahasa Latin, yaitu communicatos yang berarti berbagi atau menjadi milik bersama. Kata sifatnya communis yang bermakna umum atau bersama-sama (Marhaeni, 2009: 31).

Komunikasi menjadi sangat penting untuk membangun solidaritas sebagaimana menurut Nina W. Syam Komunikasi dan solidaritas adalah suatu kajian yang hubungannya dengan kehidupan manusia, keduanya lahir melalui 
proses sosial dalam bentuk interaksi sosial. Dan komunikasi menjadi unsur penting dalam kehidupan sosial. Seperti dijelaskan oleh Nina bahwa sosiologi menjelaskan komunikasi menjadi unsur terpenting dalam seluruh kegiatan manusia. Kontak sosial menjadi sangat bermakna karena ada komunikasi sehingga kehidupan sosial akan menjadi hidup; tanpa komunikasi interaski sosial tidak akan terjalin (Nina, 2012: 80).

\section{HASIL DAN PEMBAHASAN}

Berlokasi di Kedusunan Pasirpanjang, Desa Kalimanggis, Kecamatan Manonjaya, Kabupaten Tasikmalaya, Propinsi Jawa Barat. jarak dari Kota Tasikmalaya 13 km. ke arah Timur, dari ibu kota Kecamatan $1 \mathrm{~km}$. ke arah Tenggara dan $8 \mathrm{~km}$. dari ibu kota Ciamis ke arah Barat Daya. Dan telah mencatatkan diri sebagai Yayasan dengan nama Yayasan Pesantren Miftahul Huda (YAMIDA) dengan akta notaris Ryono Roeslam NO.34/PN/76/AN. Berhubung banyak pendirinya yang telah meninggalkan Pesantren (waktu itu pengurusnya ada dari kalangan santri senior). maka akta notaris ini diperbaharui pada tanggal 20 Juni 1987 di hadapan notaris Tuti Asijati Abdul Ghani SH.

Cikal bakalnya adalah Pondok Pesantren Wanasuka di kampung Cigugur Ciamis. kemudian karena pergolakan perjuangan pada saat itu Pondok Pesantren Wanasuka tidak dapat dilanjutkan. Beberapa tahun kemudian KH. Choer Affandi mendirikan lagi Pondok Pesantren dengan nama Pesantren Gombongsari di kampung Cisitukaler desa Pasirpanjang. kemudian karena di lokasi ini tidak memungkinkan untuk diperluas lokasinya, sementara Santri bertambah terus, atas dukungan masyarakat lokasinya dipindah ke lokasi sekarang, dibangun di atas tanah waqaf dari Raden Hj. Mardiyah seorang aghniya di Manonjaya.

Kini terletak di areal tanah seluas 8 hektar, dihuni lebih dari 3.000 santri dan memiliki 1.000 lebih cabang Pesantren yang tersebar di Daerah Jawa dan Sumatera. merupakan lembaga pendidikan Islam yang dengan segala kelebihan dan kekurangannya. Pessntren Miftahul Huda selalu mengupayakan agar para santrinya mampu berakhlaqul karimah dan mendapat ilmu yang bermanfa'at yang dituangkan dalam tiga program Pesantren. yaitu; 1. Ulama Al'Amilin (Ulama yang mampu mengamalkan ilmunya), 2. Imamal Muttaqin (Memimpin ummat untuk bertaqwa), 3. Muttaqin (Manusia yang bertahan dalam ketaqwaan).

Kondisi Sosio-Geografis Pondok Pesantren Miftahul Huda Manonjaya. Pondok Pesantren Miftahul Huda Manonjaya Kabupaten Tasikmalaya. Berlokasi di Kedusunan Pasirpanjang, Desa Kalimanggis, Kecamatan Manonjaya, Kabupaten Tasikmalaya, Propinsi Jawa Barat. jarak dari Kota Tasikmalaya $13 \mathrm{~km}$. ke arah Timur, dari ibu kota Kecamatan $1 \mathrm{~km}$. ke arah Tenggara dan $8 \mathrm{~km}$. dari ibu kota Ciamis ke arah Barat Daya.

Berbicara pondok pesantren miftahul huda maka tidak akan lepas dari peran pendiri pesantren yaitu KH. Choer Affandi (Uwa Ajengan), Pada akhir tahun 1962 M. Uwa Ajengan berusia 40 tahun memasuki daerah Manonjaya tepatnya di daerah Cisitu bersama putra pertamanya KH. Abdul Fattah sekaligus sebagai ajudan 
pribadinya. Yang menjadi dasar Uwa Ajengan datang ke Manonjaya karena di daerah Manonjaya ada tiga alumni pesantren Wanasuka (pesantren pertama yang didirikan oleh Uwa Ajengan) yaitu ajengan Abdul Manan di Manonjaya sebelah barat, ajengan Abdurrosyid di Cikareo, Manonjaya dan ajengan Abad menantu abah Sukaeji yang masih adik ipar Uwa Ajengan, dan beliaulah orang yang pertama menerima Uwa Ajengan, sehingga kurang lebih tiga bulan Uwa Ajengan tinggal bersamanya. Dan karena daerah Manonjaya merupakan lokasi yang strategis karena letaknya pertengahan di antara tempat kelahiran Uwa Ajengan di Cigugur Ciamis dan kota Bandung. Selanjutnya Uwa Ajengan pindah ke rumah ajengan Uho yang ada didepan (emper, B. Sunda) rumah mertuanya ajengan Abad dan tinggal kurang lebih enam bulan. Selama itu pula Uwa Ajengan selain membantu masyarakat sekitar baik dalam hal pengobatan, masalah keluarga atau pun dimintai do'a beliaupun mempunyai kegiatan mengajar ahli berjama'ah (berjama'ah sholat) di tajug (mushola) embah Jahidi bapaknya KH. Dudung SM mantan kepala sekolah MI Cisitu, dan pengajian mingguan di madrasah bapak H. Junaedi di Jalan Haji Zaenal Musthofa (Hazet) Nagarawangi kota Tasikmalaya selama enam tahun. Ahli pengajian dari semua golongan baik persis, NU ataupun Muhammadiyah oleh Uwa Ajengan di didik asmaul husan dan ilm-u tauhid sehingga dapat diterima oleh semua golongan tersebut.

Padahal sebelum Uwa Ajengan mengisi pengajian mingguan di daerah tersebut pengajian hanya dilaksanakan di tiap-tiap golongan, golongan NU mengadakan pengajian setiap malam jum'at,dan pengajian Muhammadiyah setiap malam sabtu. Karena memang tujuan utama Uwa Ajengan adalah mengarahkan kepada persatuan dan kesatuan umat Islam. Asal mula Uwa Ajengan mengisi pengajian di daerah tersebut Uwa Ajengan pernah di undang oleh bapak H. Onek seorang pengusaha CV. Bengawan untuk ceramah pada acara walimah nikah putranya. Kemudian masyarakat sekitar tertarik oleh ceramah Uwa Ajengan, sehingga Uwa Ajengan ditawari untuk mengisi pengajian secara rutin di daerah tersebut. Besarnya kepercayaan masyarakat tersebut terhadap Uwa Ajengan, dalam hal transportasi kepengajian beliau selalu dijemput secara bergiliran oleh kelompok NU dan Muhammadiyah, paling sering beliau di jemput dengan kendaraan beroda dua (motor jawa) dan delman, bahkan kadang dijemput dengan mobil sedan milik tokoh Muhammadiyah.

Uwa Ajengan pun mempunyai pengajian bulanan di pesantren KH. Udin daerah Ciherang, Awipari Kecamatan Cibeureum, Tasikmalaya yang masih sahabat sepesantren beliau di Sukamanah, Singaparna asuhan KH. Zaenal Musthofa. Saking simpatiknya masyarakat Ciherang yang di murobbikan oleh KH. Udin kepada Uwa Ajengan mereka bergotongroyong membelikan rumah panggung untuk Uwa Ajengan dari ustad Siroj seharga Rp. 250.000 (harga pada tahun itu). Rumah tersebut di gotong oleh kurang lebih 200 masyarakat Ciherang di pindahkan ke Cisitu kaler dan di simpan di atas tanah milik bapak H. Kosasih, karena memang Uwa Ajengan belum mempunyai tanah sendiri. Kemudian Uwa Ajengan bermaksud untuk membeli tanah tersebut dari bapak H. Kosasih namun 
beliau enggan menjualnya, apalagi untuk di jariyahkan. Hingga akhirnya Uwa Ajengan lebih memilih menumpang saja. Dan disanalah (Cisitu kaler) Uwa Ajengan pertama kali mengajar, di antara murid pertama beliau adalah $\mathrm{KH}$. Abdul Fatah, KH. Khoeruman Azam, Ajengan Otoh dan yang lainnya.

Tak lama setelah Uwa Ajengan mukim di cisitu datanglah gurunya $\mathrm{KH}$. Raden Didi Abdul Majid Salah seorang murobbi Uwa Ajengan yang terakhir meninggal dunia. Beliau datang sampai tiga kali berturut-turut. Pada bulan pertama sang guru menemui Uwa Ajengan beliau langsung menatap Uwa Ajengan sambil menangis terdiam tak mengucapkan sepatah katapun, karena melihat keadaan dan kepedihan Uwa Ajengan sang muridnya. Pada bulan selanjutnya KH. Raden Didi Abdul Majid datang kembali menemui sang murid, Uwa Ajengan. Dan beliau amanat kepada Uwa Ajengan : "Jika ingin manfaat ilmu diam di sini! (Manonjaya) jangan pergi ke manapun juga namun jika tidak ingin manfaat ilmu terserah (pergi kemana saja).

\section{Sistem Budaya Komunikasi di Pesantren Miftahul Huda Manonjaya}

Komunikasi menjadikan hal yang penting bagi kehidupan manusia, baik itu secara individu ataupun kelompok, begitu pula di pesantren miftahul huda manonjaya salah satu pesantren dengan metode salaf yang mempunyai ribuan santri dari berbagai daerah di Indonesia, tentu memerlukan komunikasi yang baik agar tujuan belajar mengajar tercapai.

Di samping ribuan santri aktif, pesantren miftahul huda manonjaya juga telah melahirkan ribuan alumni yang tersebar di berbagai daerah yang mana sampai saat ini masih berkomunikasi baik dengan pihak pesantren. Pesantren miftahul huda manonjaya mempunyai tri motto pesantren yaitu mencetak Ulamaul Amilin, Imamal Muttaqin, dan Muttaqin. Agar alumni bisa menyebarkan ilmu agama islam di tengah-tengah masyarakat dan berperan aktif dalam mensyiarkan agama islam di masyarakat. Sehingga kyai di pesantren miftahul huda terus memantau kegiatan-kegiatan santri setelah menjadi alumni pesantren. Maka ada beberapa bentuk komunikasi yang di budayakan di lingkungan pesantren miftahul huda manonjaya dari mulai menjadi santri sampai menjadi alumni pesantren.

Berdasarkan wawancara yang dilakukan kepada salah satu kyai, terdapat budaya komunikasi yang di bangun baik itu antara guru dengan murid ataupun guru dengan alumni dengan cara menceritakan apa yang di lakukan oleh pendiri pondok pesantren miftahul huda manonjaya Almarhum KH. Choer Affandy, sehingga dengan model seperti itu membangun semangat kebersamaan baik itu kepada santri maupun alumni pesantren.

Senada dengan informan kedua KH. Asep A.Maousul Affandy (Pimpinan Umum Pesantren),

"Bukan hamba dengan bos atau hamba dengan Tuhan komunikasinya malah komunikasi lebih ke persaudaraan antara anak dengan bapak jadi anak dengan bapak itu lebih dahsyat hubungannya, ada satu rasa kasih sayang makanya terkadang dari pimpinan umum atau dewan kyai turun kebawah 
tidak melihat kondisi alumni itu dalam mapan atau tidak mapan secara ekonomi, sehingga andai kata ekonomi melemah perlu di bantu ya di bantu dengan menjalin solidaritas dengan sesama kawannya, lalu kemudian kalau mereka punya lebih bagaimana juga orang yang lebih ini bisa berbagi dengan yang lain dengan kawannya juga, karna memang diurus komunikasinya sehingga persamaan visi misi itu terjaga."

Di lihat dari pernyataan di atas terlihat ada bentuk komunikasi yang di bangun oleh kyai terhadap santri ataupun alumni pesantren dengan model kekeluargaan, baik itu secara orang tua terhadap anak ataupun anak terhadap orang tuanya, Hal ini menggambarkan adanya keakraban dan semangat kepedulian yang diberikan oleh kyai kepada santri dan alumni.

Hal ini menggambarkan adanya pembinaan dari kyai sebelum santri di lepas untuk dakwah di masyarakat, ada beberapa kebiasaan yang di terapkan oleh lembaga pesantren dan juga ada kewajiban-kewajiban yang harus di ikuti oleh alumni yang baru terjun dakwah di masyarakat, seperti ada kewajiban untuk mengikuti program-program yang di laksanakan oleh lembaga alumni pesantren yaitu Himpunan Alumni Miftahul Huda (HAMIDA). Sehingga di awal menjadi alumni akan terus terjalin komunikasi yang baik dengan pihak pesantren.

Di tambahkan kembali oleh KM. Syaqiq Marbawi (Pengajar di Pesantren Miftahul Huda),

"Di pesantren miftahul huda kami selalu melakukan pendekatanpendekatan dengan santri ataupun alumni, karena demi keberhasilan tujuan pesantren itu harus di lakukan. Contohnya seperti ada santri lewat di depan kita baik itu ketika di depan rumah ataupun di tempat lain, kami panggil karena ingin mengenalnya, maklum karena banyaknya santri kami tidak bisa mengenalnya langsung kecuali kalau ka ajar langsung di kelas, kami sapa namanya siapa? di tanya orang mana? Ke pesantren miftahul huda dapat informasi dari mana? Apakah dari kerabat yang alumni sini, ataupun putra dari alumni sini. Baik ke santri baru ataupun ke santri lama yang masih samar dalam mengenalnya. Nah hal-hal seperti itu lebih mendekatkan kita terhadap santri, jadi mereka itu merasa di aku dan supaya tidak lagi sungkan terhadap kami para pengasuh di pesantren".

Pendekatan-pendekatan melalui komunikasi yang di bangun baik pihak kyai dan para pengajar di pesantren tidak lain untuk menyampaikan pesan semangat membangun visi bersama, tujuan bersama sehingga adanya feedback timbal balik dari santri ataupun alumni terhadap pesantren. Dengan demikian maka akan tercipta budaya komunikasi yang khas di lingkungan keluarga besar pondok pesantren miftahul huda manonjaya.

Di tambahkan juga oleh muhammad wafiq (santri Pesantren Miftahul Huda tingkat Ibtida)

"Ya saya selaku santri menurut saya sungguh besar guru dalam pengorbanannya, karena menganggap santri itu sebagai anaknya sendiri. 
Dan kita sebagai santri juga harus patuh, taat atas perintah guru, harus hormat dan ta'dzim Ketika ada perintah maka kita harus turut. Ketika saya sebagai santri di panggil oleh guru itu sangat senang sekali, karena kita santri selalu berharap ingin dekat dengan gurunya. Bukti tanda dekatnya guru terhadap santri apabila guru sering memerintahkan kepada santri, sering berbicara, sering berkomunikasi itulah yang di harapkan oleh santri supaya dekat dengan guru dan ingin bermanfaat apa yang telah di perintahkan oleh guru. Jadi ada kebanggaan tersendiri ketika ada perintah dari kyai”.

Beragam komunikasi yang di bangun pihak kyai terhadap santri membuat santri ingin lebih dekat dengan kyai sebagai gurunya bahkan lebih dari itu yaitu sebagai orang tua asuhnya. Sebagaimana yang di sampaikan informan di atas ada rasa bangga, ada rasa senang ketika di panggil atau di sapa oleh sang kyai karena mereka menganggap hal tersebut lebih mendekatkan rasa emosional antara murid dengan guru sehingga tumbuhlah komunikasi yang baik bagaikan anak terhadap orang tuanya. Huda),

Hal yang sama di sampaikan oleh De Ali (Santri senior pesantren Miftahul

"Kami sebagai santri lama merasa tidak sungkan lagi terhadap para guru di pesantren dengan catatan tetap tidak mengurangi rasa hormat kami. Bertahun-tahun kami di didik dan di tanamkan tauhid, keagamaan dan ilmuilmu yang berguna di masyarakat serta kami di ajarkan mempunyai rasa tanggung jawab baik terhadap ma'had dan para guru kami. Beliau para kyai tak pernah bosan untuk mengajarkan kami, membimbing kami agar bisa berperan aktif di masyarakat menyampaikan risalah-risalah kenabian. Maka sebelum kami di terjunkan ke masyarakat kami di bina agar mempunyai mental yang kuat, komunikasi yang cakap, tata cara kehidupan sehari-hari di masyarakat sehingga bisa bermanfaat di lingkungan masyarakat. Hal-hal tersebut selalu di tanamkan oleh para kyai kami dalam setiap kesempatan. Dari awal saya masuk ke pesantren sampai tingkat ibtida (awal) sampai sekarang tingkat ma'had 'aly (akhir) beliau para kyai selalu melakukan pendekatan-pendekatan kepada kami, sehingga kami pun ingin selalu mendekat kepada beliau para guru kami, karena ilmu yang kami dapat bukan hanya di dalam kelas di luar kelas pun ketika kami berdekatan dengan beliau para kyai kami selalu mendapatkan ilmu dari sisi manapun".

Maka dapat disimpulkan sistem budaya komunikasi di Pesantren Mifhatul Huda Manonjaya dengan mengadopsi dari ilmu tafsir biroyah, riwayah, isaroh atau dengan menceritakan historis perjuangan sang pendiri KH. Choer Affandy juga dengan pendekatan-pendekatan yang di bangun oleh kyai kepada santri dan kyai kepada alumni dengan pendekatan pola asuh sehingga muncul rasa kekeluargaan dan semangat ingin seperti beliau pendiri pesantren. Sehingga tercipta rasa ingin membangun dan mengembangan pondok pesantren dengan visi misi yang sama.

\section{Bentuk Komunikasi Kyai dengan Santri Pesantren Mifhatul Huda Manonjaya}


Berdasarkan hasil observasi di lapangan di pondok pesantren miftahul huda terdapat ribuan santri dari di berbagai daerah, baik itu daerah jawa barat ataupun daerah lainnya. Santri baru yang awal datang ke pondok pesantren miftahul huda manonjaya biasanya di antarkan oleh orang tuanya setelah selesai secara administrasi, di pesantren miftahul huda manonjaya ada budaya ijab qobul antara orang tua santri kepada kyai di pesantren, orang tua langsung berhadapan dengan kyai dan menyerahkan anaknya untuk di didik di pesantren miftahul huda manonjaya, jadi di awal kedatangan santri pihak pesantren melalui para kyai sudah menjalin komunikasi terhadap orang tua santri. Bentuk komunikasi kyai dengan santri di pesantren miftahul huda manonjaya terdapat dua bentuk diantaranya: Pertama, Bentuk Komunikasi Orang tua dan Anak.

Jalinan komunikasi yang di bangun sejak awal masuk oleh kyai terhadap orang tua santri membuat hubungan antara kyai dengan santri bukan hanya sebatas guru dan murid ada ikatan orang tua terhadap anaknya, sehingga komunikasi menjadi lebih mudah di lakukan. Karena di awal pertemuan langsung kyai dengan orang tua terjadi perbincangan-perbincangan yang mengarah kepada komunikasi tindak lanjut

Kedua, Bentuk Komunikasi Guru dengan Murid. Pesantren Miftahul huda adalah salah satu lembaga pendidikan keagamaan yang sampai saat ini terus melakukan proses pendidikan layaknya sekolah formal yakni masuk kelas atau belajar di dalam kelas, sehingga komunikasi terjalin dengan suatu kegiatan pembelajaran di kelas dengan kitab-kitab klasik. Pada pelaksanaan kegiatan belajar mengajar terjadi suatu komunikasi antara guru dengan murid yang menghasilkan suatu komunikasi yang efektif agar tercapainya tujuan dari belajar tersebut.

Sebagaimana menurut informan ketiga KM. Syaqiq Marbawi beliau mengatakan,

"Bahwa santri di pesantren miftahul huda ada tiga tingkatan, pertama tingkat ibtida satu, dua, dan tiga(awal), selanjutnya tingkat tsanawi satu, dua, dan tiga (menengah) dan yang terakhir tingkat Ma'had 'Ali satu, dua, tiga sampai empat (akhir) adapun kalau pengurus pondok pesantren itu di sebutnya Khodimul Ma'had. Nah tentunya dari tingkatan itu ada beberapa bentuk komunikasi yang kami bangun, misalnya untuk tingkat ibtida (awal) lebih kepada pola asuh kepada anak karena di tingkat ibtida santri usianya rata-rata sekitar 13 tahun (lulusan sekolah dasar) biasanya untuk tingkat ibtida kami lebih menekankan kepada pembelajaran dan penalaran (hafalan) karena di usia tersebut santri lebih mudah untuk menghafal, sedangkan untuk tingkat tsanawi (menengah) kami lebih membawa kepada hafalan dan pemahaman juga mulai diajarkan dewasa dalam bersikap, dan untuk tingkat ma'had 'ali (akhir) lebih kepada mematangkan pembelajaran dari awal karena akhir dari ma'had 'ali yaitu wisuda santri sudah siap terjun di masyarakat. Maka komunikasi yang di bangun oleh kami sebagai pengajar lebih kepada pendekatan individual santri agar lebih bisa menguasai materimateri dari masing-masing tingkatan”. 
Secara psikologis tentu dengan bertambahnya usia maka akan berubah pula dari segi fisik, pemikiran dan cara komunikasi. Di pesantren miftahul huda manonjaya ada tiga tingkatan sistem pembelajaran, maka dari segi usia pun tentu berbeda. Perbedaan usia dan tingkatan akan membuat bentuk komunikasi yang di bangun oleh kyai juga berbeda sesuai dengan kebutuhannya. Walaupun secara pendekatan masih sama dengan metode belajar mengajar dan pola asuh yang baik.

Komunikasi yang terjadi dalam proses pembelajaran di pesantren miftahul huda manonjaya yaitu antara hubungan guru dan murid tetap terjalin walaupun komunikasi dengan bentuk pola asuh lebih mendominasi di pesantren miftahul huda manonjaya. Namun dengan demikian santri di pesantren miftahul huda manonjaya tetap menjaga kaidah selayaknya santri antara guru dengan murid.

Ditambahkan oleh informan keempat Muhammad Wafiq, mengatakan, "Saya sebagai santri merasa bangga ketika di sapa oleh kyai, merasa bangga apabila mendapatkan tugas dari murobby, karena kami meyakini ketika kami di panggil di butuhkan oleh para guru kami, akan mendapatkan barokah yang berlimpah, di samping saya ngaji di kelas saya juga suka mengikuti kegiatan berbentuk tawasul yaitu terjun ka proyek pembangunan karena ada poin tersendiri yaitu di samping ngalap barokah dapat ilmu pembangunan atau ilmu pertanian yang nantinya di perlukan saat di masyarakat".

Senada dengan informan di atas salah satu alumni pesantren miftahul huda Ust. Abu Bakar Shidiq, Beliau mengatakan,

"Tradisi di pesantren miftahul huda hampir tidak berubah selalu menjaga marwah pendiri selalu menjaga tradisi-tradisi yang di tanamkan oleh pendiri pesantren, adapun proses komunikasi yang di bangun oleh para guru kami, kyai kami yang selalu menceritakan historis perjuangan pendiri pesantren. Dengan demikian ada rasa ghiroh semangat kami dalam membangun pesantren yang telah mendidik kami. Bentuk komunikasi yang di lakukan oleh para guru kami dengan pendekatan-pendekatan yang sangat lembut sehingga kami para santri ketika di pondok di bentuk memiliki rasa tanggung jawab, sehingga dengan sendirinya kami sadar apa yang harus kami lakukan apa yang harus kami kerjakan. Selain kami mendapatkan pendekatan dengan pola asuh dari para guru kami, kami juga mendapatkan proses pembelajaran di kelas yang tak luput dari bimbingan guru".

Maka dapat disimpulkan bentuk komunikasi antara kyai dan santri adalah adanya pola asuh yang di berikan oleh kyai terhadap santri sehingga terjalin komunikasi dinamis dan humanis, karena masing-masing pihak antara kyai menganggap para santri bukan hanya seorang murid tapi lebih dari itu yaitu keluarga yang sudah di amanahkan oleh pihak orang tua kepada pihak pesantren, begitupun seorang santri yang menganggap para kyai bukan hanya seorang guru tapi orang tua yang selalu membimbing dan mengarahkan santri untuk bisa belajar dan menguasi materi yang di berikan oleh para Kyai. 


\section{Bentuk Komunikasi Kyai dengan Alumni Pesantren Mifhatul Huda Manonjaya}

Pondok pesantren miftahul huda manonjaya berdiri sejak tahun 1967 Masehi tepatnya pada tanggal 07 Agustus, maka sudah tentu telah melahirkan ribuan alumni yang tersebar di berbagai wilayah Jawa Barat dan daerah lainnya di Indonesia. Dengan banyaknya alumni tersebut tentu di perlukan wadah organisasi agar komunikasi bisa berjalan dengan lancar.

Alumni pondok pesantren miftahul huda manonjaya yang tersebar di berbagai wilayah Indonesia tentu dengan berbagai latar belakang pekerjaan, suku dan bahasa. Maka di perlukan bentuk-bentuk komunikasi agar para alumni bisa terus menjalin hubungan baik dengan pihak pesantren dan kyai.

Konteks tujuan dari komunikasi yang di bangun kyai yaitu menyamakan visi misi dari alumni dengan pihak pesantren, membangun harmoni antara kyai dan alumni. Karena dari berbagai aktivitas komunikasi yang di lakukan oleh kyai terhadap alumni menggunakan pendekatan-pendekatan secara primordial. Proses komunikasi intens di lakukan oleh pihak pesantren karena dalam hal ini pimpinan umum dan para dewan kyai selalu merangkul seluruh elemen alumni tidak pandang bulu.

Komunikasi di bangun bukan hanya sebatas membangun ghiroh yang sama, lebih dari itu untuk meningkatkan solidaritas alumni terhadap para kyai utamanya terhadap pesantren miftahul huda manonjaya. Solidaritas alumni juga bukan hanya kesolidan alumni terhadap pesantren tetapi kesolidan alumni dengan alumni yang lainnya.

Banyaknya alumni di pesantren miftahul huda dengan latar belakang yang berbeda. tentu perlu komunikasi yang relevan agar proses komunikasi berjalan lancar, banyaknya problematika yang terjadi di lapangan maka kerap kali kyai turun tangan dalam penyelesaian problem tersebut dengan cara komunikasi langsung atau tatap muka. Bahkan pada momen tertentu seperti momen politik yang terjadi di tahun politik, alumni sering kali meminta pendapat dan arahan dari para kyai di pesantren, maka di situ terjadilah komunikasi politik.

Berdasarkan hasil pemaparan di atas, problematika-problematika yang terjadi di alumni pesantren miftahul huda baik itu politik ataupun problematika yang lainnya maka akan di selesaikan dalam forum musyawarah, dengan melibatkan Alumni, Koordinator Alumni dan Ketua Alumni. Sehingga hasil keputusan terakhir adalah hasil keputusan bersama. Seiring berkembangnya zaman maka komunikasi antara kyai dengan alumni juga menggunakan alat komunikasi melalui media sosial agar lebih memudahkan dan efisien dalam berkomunikasi.

Komunikasi yang di bangun ada yang bentuknya pola asuh ada juga yang bentuknya intruksional sehingga ada yang jalur individu ada pula yang jalur organisasi alumni yaitu HAMIDA, sehingga dengan demikian komunikasi berjalan dengan terstruktur. Komunikasi juga berjalan pada momen pertemuan bulanan, alumni bisa komunikasi dengan kyai yang bertugas pada bulanan 
tersebut.

Peran kyai sangat berpengaruh terhadap solidaritas alumni pesantren, karena di lakukan pendekatan-pendekatan secara psikologis sehingga terbangun emosional antara alumni dan kyai, alumni selalu berharap bimbingan dan arahanarahan dari kyai. Karena pada awal menjadi santri sampai menjadi alumni selalu berkomunikasi dalam segala hal dalam kehidupan sehari-hari bahkan dalam keluarga pun alumni tidak segan-segan bercerita kepada kyai untuk mendapatkan solusi terbaik dalam kehidupannya. Bahkan dalam hal perjodohan alumni kyai membahasnya dalam forum musyawarah kyai dan keluarga. Dalam hal ini menandakan kepedulian kyai terhadap alumni begitu besar.

Peran kyai terhadap alumni di rasakan langsung oleh alumni dari mulai menjadi santri sampai menjadi alumni, karena dengan tercapainya suatu komunikasi oleh komunikator terhadap komunikan menjadikan komunikasi semakin relevan dan komunikatif, apalagi ada feedback dari komunikasi tersebut. Sehingga dengan demikian komunikasi yang di bangun oleh pendiri pesantren miftahul huda Al-marhum KH. Choer Affandy di pertahankan oleh para generasi penerusnya.

Maka dapat disimpulkan bentuk komunikasi antara kyai dan alumni itu ada jalur intruksional secara organisasi, ada juga jalur pola asuh bagaikan anak dan orang tua dan orang tua dengan anaknya, karena dalam proses komunikasinya itu bisa kapan saja di lakukan dengan terbuka, dan juga karena ada kegiatan rutin atau pertemuan rutin baik itu bulanan, triwulan, ataupun tahunan disitu ada waktu untuk berdiskusi dan bercengkrama menyampaikan persoalan-persoalan baik itu personal maupun organisasi.

\section{PENUTUP}

Peran kyai sangat berpengaruh terhadap solidaritas alumni pesantren, karena di lakukan pendekatan-pendekatan secara psikologis sehingga terbangun emosional antara alumni dan kyai, alumni selalu berharap bimbingan dan arahan-arahan dari kyai. Karena pada awal menjadi santri sampai menjadi alumni selalu berkomunikasi dalam segala hal dalam kehidupan sehari-hari bahkan dalam keluarga pun alumni tidak segan-segan bercerita kepada kyai untuk mendapatkan solusi terbaik dalam kehidupannya. Bahkan dalam hal perjodohan alumni kyai membahasnya dalam forum musyawarah kyai dan keluarga. Dalam hal ini menandakan kepedulian kyai terhadap alumni begitu besar.

Peran kyai terhadap alumni di rasakan langsung oleh alumni dari mulai menjadi santri sampai menjadi alumni, karena dengan tercapainya suatu komunikasi oleh komunikator terhadap komunikan menjadikan komunikasi semakin relevan dan komunikatif, apalagi ada feedback dari komunikasi tersebut. Sehingga dengan demikian komunikasi yang di bangun oleh pendiri pesantren miftahul huda Al-marhum KH. Choer Affandy di pertahankan oleh para generasi penerusnya.

Maka dapat disimpulkan bentuk komunikasi antara kyai dan alumni itu ada 
jalur intruksional secara organisasi, ada juga jalur pola asuh bagaikan anak dan orang tua dan orang tua dengan anaknya, karena dalam proses komunikasinya itu bisa kapan saja di lakukan dengan terbuka, dan juga karena ada kegiatan rutin atau pertemuan rutin baik itu bulanan, triwulan, ataupun tahunan disitu ada waktu untuk berdiskusi dan bercengkrama menyampaikan persoalan-persoalan baik itu personal maupun organisasi.

\section{DAFTAR PUSTAKA}

Amin, M. (2011). Teori-Teori IImu Dakwah, Cet.1, Makasar: Alauddin Press.

A.W. Widjaja. (2010). Komunikasi: Komunikasi dan Hubungan Masyarakat. Jakarta: PT. Bumi Aksara.

Fatah, A. (2013). Ua Ajengan. Ciamis : Galuh Nurani

Muis, A. (2001). Komunikasi Islam. Bandung: Remaja Rosdakarya.

Hasbullah. (2001). Sejarah Pendidikan Islam di Indonesia. Jakarta: Raja Grafindo Persada.

Effendi, O. U. (2003). Ilmu, Teori dan Filsafat Komunikaai. Bandung: PT Citra Aditya Bakti.

Fajar, M. (2009). Ilmu Komunikasi Teori \& Praktik. Yogyakarta: Graha Ilmu.

Syam, N. W. (2012). Sosiologi Sebagai Akar Imu Komunikasi. Bandung: Simbiosa Rekatama Media.

Sobur, A. (2006). Ensiklopedia Komunikasi. Jakarta: Simbiosa

Wiryanto. (2004). Pengantar Ilmu Komunikasi. Jakarta: Gramedia. 